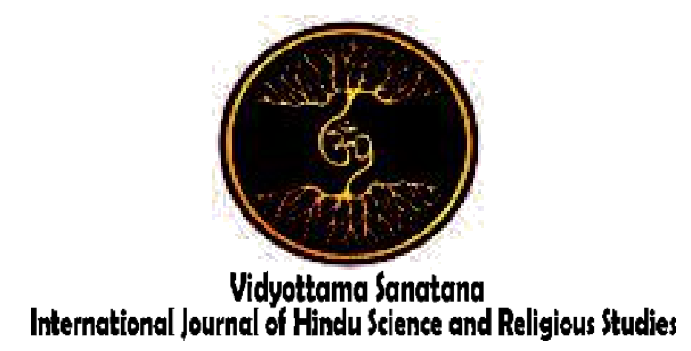

Vol. 3 No. 1 May 2019

\title{
POSITION TAPINI IN YAJÑA CEREMONY: PERSPECTIVE TEALOGI HINDU
}

\author{
By: \\ Ida Ayu Tary Puspa, Ida Bagus Subrahmaniam Saitya \\ Institut Hindu Dharma Negeri Denpasar \\ E-mail : dayu.tary26@mail.com
}

\begin{tabular}{|l|l|l|}
\hline Received: Desember 16, 2018 & Accepted: May 19, 2019 & Published: May 31, 2019 \\
\hline
\end{tabular}

\begin{abstract}
Tapini has a strategic position in the yajña ceremony This feminist figure in the perspective of Hindu theology has been able to become a ceremonial leader even though it is customary to wait until the Pedanda dies. However, sometimes also in a Pakraman Village such as Sanur, the Pedanda of the one who has not died gives Pedanda his wife the opportunity to become the leader of the ceremony when she is overwhelmed to accept the wishes of Hindus so that she becomes the leader of the yajña ceremony. This shows that the current relationship in the position of leader of the ceremony is a serious challenge because a Tapini must also be an expert in the position of Goddess, as a teacher, and as an tukang banten.
\end{abstract}

Keywords: Position, Yajña Ceremony, Tealogi

\section{Introduction}

Offering in the yajña ceremony can be in the form of upakara or banten. For the making of this banten for certain ceremonies such as the ngenteg linggih ceremony, the Ngaben ceremony, banten panjang ilang matah dan lebeng, banten catur will be made by Tapini. The implementation of a yajña ceremony must have the Sadhaka (Leader of the Ceremony), Sang Anukangi
(Tapini), and the Yajamana (Those who own or carry out yajña). Tapini is when someone who has been medwijati and is a Pedanda Istri. In addition to Tapini in sekala is Pedanda Istri, then in ngenteg linggih ceremony there will be a ngadegang Bhatari Tapini ceremony. So in this Hindu Goddess/Bhatari theology Tapini is a Bhatari/Goddess who has expertise in bebantenan As in Desa Pakraman Sanur, 
Tapini addition to having authority in bebantenan, then Tapini also

conducting lokapala sraya although Pedanda Lanang si still alive and well nglokapalasraya. Besides that, in Siwa-Sisya's relationship concept, then if there are sisya having a yajñ ceremony, then Tapini will present at the home of his sisya to make bebantenan.

From the above explanation, the Tapini that a Pedanda Istri has a position that is quite strategic and complex because in addition to being an expert bebantenan, he also will be a leader ceremony. When viewed from the perspective of tealogi, this is a progress in terms of women's struggle to be Tapini complete, it turns out that a woman is intelligent in carrying out the yajña ceremony.

\section{Methods \\ 2.1 Concept}

2.1.1 Tapini

In this concept what is meant by Tapini is sulinggih/Pedanda Istri or a woman who had diksa, in charge of realizing its offerings in swadharma guided by the rules concerning a law because the offerings are realized procces holy and sacred meaning. In their work they will be related to moral rules or religious ethics based on tri kaya parisudha. This is also called Sang Anukaning, tapeni, sarati, and mancagra (Suparta, 1995). In the lontar of Indik Panca Krama stated

Kayatnakna, away saulah-ulah lumaku, ngulah subal, yan tan hana bener anut linging aji, nirwage pwaranya, kawalik purihnya ika, amrih ayu byakta atemahan ala Mangkana wenang ika kapratyaksa de sang anukaning sang andiksan, ika katiga wenang atunggalah plaksana nira among saraja karya

Translation :

Be careful and careful, do not just do/carry out yajña or do not carry out a yajña which is carelessly done. If it is not in accordance with the provisions of religious literature, the results will be in vain, on the contrary it will be obtained, hoping for a sure good, expecting a sure good that is not good results. Thus should be watched out by the artisans of offerings, andiksani (sulinggih the mupu) and those who have yajña, all three of which should unite their views and steps in implementing yajña .

\subsubsection{Yajña Ceremony}

According to the Decision Pesamuhan Agung of Parisada Hindu Dharma Indonesia Center in Denpasar on November 4, 2007 the ceremony or upacara originated from the Sanskrit syllable "Upa" which means "Relationship" and "Car" which means motion or action gets a suffix a verb meaning movement. So upacara is something that has to do with the movement (implementation) of a yajña (action). In line with that Titib (1998:147) explains that literally the procedure for implementing a yajña is called a ceremony. The word ceremony in Sanskrit means approaching. In religious ceremonies it is hoped that an effort will be made to get closer to Hyang Widhi Wasa, to fellow human beings, to the environment, pitara and receipt. The approach was manifested in various forms of offerings and procedures as stipulated in the teachings of Hinduism. Chastity is the nature of God. People must be pure and inner if they want to say a prayer and draw closer to God. The ceremony gives its own identity for certain religions that distinguish it from other religions. Each religion has rules in the administration of the ceremony.

Hindus in Bali recognize the facilities as Hindu ceremonial equipment. The Hindu ceremonial facilities consist of various types of symbols which include the literary level, symbol images, and various types of offerings in banten. The ceremony is implemented through yajña. The definition of yajña according to Titib (1998: 147) comes from the word yaj (Sanskrit) which means sacrifice of worship. Yajña means 
sacrificial ceremony. As a worship that uses sacred sacrifices, then yajña requires the support of a holy mental attitude as well, in addition to the means to be sacrificed. The meaning and purpose of implementing yajña is as an embodiment of Vedic teachings, as a spark of gratitude, to improve self-quality, as a way to connect with a worshiped God, and to purify.

The commonly

or yajña classification is

known type

on yajña goals or objectives it was offered. In this connection Agastya Parwa describes as follows:

Kunan ikan yajña lima pratekanya, lwirnya: deva yajña, rsi yajña, pitra yajña, bhuta yajña, menusa yajña; nahan tan panca yajña rin loka. Deva yajña naranya taila pwa krama ri bhatara siwagni makagelaran in mandala rin bhatara, yeka deva yajña naranya, rsi yajña naranya, kapujan san pandita mwan san wruh ri kalinganin dadi wwan ya rsi yajña naranya. Pitra yajña naranya tilemin bwat hyan siwasraddha, yeka pitra yajña naranya. Butha yajña naranya tawur wwan kapujan in tuwuh ada pamuwan kunda wulan makadi walikrama, ekadasa dewata mandala, ya bhuta yajña naranya. Aweh amanan rin kraman ya ta manusa yajña naranya; ika ta liman wiji i sdennin lokacara manabhyasa ika makabheda lima.

Translation:

The so-called yajña are five forms, namely the Dewa yajña, rsi yajña, pitra yajña,

bhuta yajña, manusa yajña all called panca yajña. Dewa yajña is an offering ceremony to the holy fire of Siwa (Siwagni) by making mandala yajña, rsi yajña is worship of priests and people who understand the meaning of the nature of life, pitra yajña is worshiping the ancestral spirit, bhuta yajña is tawur and ceremony to plants, among others, in the form of walikrama and Eka
Dasa Rudra ceremonies and giving food to the community are called manusa yajña; that's called the five yajña, five in number, the implementation is different from each other The five yajña are carried out through ceremonies and upakara as the basis for returning three human debts (Tri Rna ) (Surayin, 2002: 1).

\subsubsection{Hindu Theaology}

Thealogy is a word derived from the Greek word meaning thea goddess. In the context of the deconstruction of the concept of The Divine according to patriarchy, the theologians explore and explore the concept of goddesses from civilization both west and east. Thealogy wants to bring up the concept of a goddess buried in the sea of sand of a civilization of religion that is in favor of men Adian, 2005:52). According Titib (2011:17) tealogi Hindus recognize the concept of sakti (power), the Vedas and Hindu literature found figures and the maharsi become Bahmawadini so that women have the opportunity to become Hindu priests.

\section{Results And Discussion 3.1 Tapini Position as a Goddess}

In worship, a ceremony of respect is given to the Gods. Thus, worship means process, method, deed, worship. The worship of Balinese society is not only against magic, but also towards God. In moving the yajña chakra, God will be accompanied by magic as a power so that the maintenance of the universe and its contents run well. Worshiping God with all its manifestations has been carried out by Balinese people who, if they are referred to in Hindu theology with their source, the Vedas, it turns out that the Balinese have worshiped the Saguna Brahman.

Even though it is called by thousands of names, actually $\mathrm{He}$ is the One, like a mantra bellow.

Indram Mitram Warunam Agnim ahur atho diwyah sa suparno Garutman, ekam satwiprabahudha wadantyagnim 
Yaman Matariswanam ahuh (Rgveda I.164.46)

Translation:

They call Indra, Mitra, Waruna, Agni, and $\mathrm{He}$ who is radiant, namely Garutma who is a beautiful wing, the One who is wise by calling it with many names such as Agni, Yama, and Matariswan.

Tad eva tad Agni tad Vayus tad $U$ Candramah, tad eva Sukr tad Brahma ta apah ca sa Prajapatih (Yajur Weda XXXII.1).

Translation:

Agni is just that, Aditya is just that, Wayu is just that, Candra is that, light is that, Brahma is that, Apah is that, Apah is that, Prajapati is that.

The word sakti comes from the word saknoti means to be strong or have strength, and often also has the meaning of energy or effective power, besides also means energy that permeates everything.This magic word is associated with the power possessed by the Gods. This power called sakti is personified as the wife of the Gods. Especially the word Sakti (with capital letters) means Durga, wife of Siwa (Liebert, 1976: 246) The word sakti in the Old Indonesian Javanese dictionary (Mandiwarsito, 1978: 285) means (1) 'sticky, loyal to, obedient, firm ', (2)' conditions (requested / required / required ').

In the form of a magic icon described in the form of a woman as the wife of the gods. The names of the goddesses of maturity such as Durga, Laksmi, Saraswati, Kali, Candi, Camundi, Tripura Sundari, Rajarajeswari, Lalita, Kundalini, and Parvati are sakti names that pair up with certain flow gods. In the Waisnawa, for example, the sakti Wisnu is manifested as Laksmi. Meanwhile, in the Siwa sakti is in the form of Goddess (Redig, 2008:107)

According to some purana, sakti or Dewi, they have two forms, namely the form of santa or somya (calm) and the form of krodha (awesome). Sakti which is classified as a santa form is Parvati (Uma), Sati, Gauri, and so on, then those belonging to the shape of the wheel are Durga, Kali, Karali, Kausaki, Candika, and so on (Santiko, 1992: $1)$.

In the book Dewi Purana, Dewi (the sakti Siwa) has three qualities, namely satwika (santa), rajasika (kroda), and tamasika or krura (scary, violent). Durga remains included in the quality of krodha, but Kali and Karali are included in the quality of tamasika or Krura (Kumar in Santiko, 1992: 1)

In Hindu mythology literature as well as in the Tantra books, this energy is always described as a female dewata, Dewi, as a companion of his dewata partner. Each Trimurti member $\mathrm{h}$ as Sakti or Dewi as his companion: Saraswati from Brahma, Laksmi from Wisnu and Parwati from Siwa. Howev er, the belief in the Mother who has developed a number of late immortals which is more prominent centers around Parwati, Siwa's companion.

Mother-worship and belief-Mother is no stranger to the Vedic religion as some have predicted. The concept of Aditi as the mother of Gods, the personification of nature and Ambhrnnisukta as well as Ratrisukta of the Rgveda clearly contain the origin of Mother-worship. In local/Balinese theology, worship of a Goddess who is Siwa's sakti is done when making a yajña ceremony. She is worshiped as the Dewan Tukang Banten in terms of offerings. To do the puja for Tapini, she is descended as the sakti Dewa, Dewi Uma as the Dewaning Tapini, in the tapakan daksina linggih. It is done in Dewa yajña ceremony is ngenteg linggih, that begins with making the tool of ceremony/offerings. That tool mainly is on make sesamuhan offerings, then Sthana is established for Ida Sang Hyang Widhi in manifestation as Tapini, which is worshiping Dewi Tukang with the intention of obtaining a blessing or blessing from him as well as instructions and guidance in carrying out the ceremony.

Hindus believe that all actions, karma, good and noble works 
are yajña. In yajña, it must be based on a clean heart and sincere, because it was presented before Sang Hyang Widhi with all his manifestations. Without yajña or sincere sacrifices, harmony and balance in life will not be achieved.

In Bhagawadgita III.11 mentioned:

Devām bhāvayatānena

te devā bhāvayantu vah,

prasparam bhāvayantah

śreyah param avāpsyatha

Translation:

The existence of the gods is because of this (yajña), May they make you that way, By giving each other you will get virtue main (Pudja, 1999: 85) .

In carrying out the yajña ceremony, the people carry out the so-called panca yajña. In this case the use of upakara always accompanies a ceremony. Included in this case is the use of daksina linggih. Almost every yajña ceremony is always made daksina, and a large ceremony uses pulagembal/sarad, especially in the ceremony of Dewa Yajña. In a ceremony honoring the goddess Tapini, then made daksina linggih to stimulate Her in Yajña ceremony. All of these facilities are manifestations of devotional service to the creator, namely Ida Sang Hyang Widhi Wasa in the manifestation of Sakti Dewa Siwa namely Dewi Uma who is none other than Dewi Tapini.

So based on the description above, it can be concluded that in order to realize God in His manifestations which cannot be reached by the human mind, various symbols (nyasa) are made, one of which is daksina linggih which is a religious symbol in the form of the belief of Hindus in realizing sraddha and bhakti before the Creator.

\subsection{Tapini Position as a Guru}

Guru have a very respectable position in society, especially among Hindus who position guru as a very noble position, as noted in the following sloka quote.
Kare saghyatyagah sirasi Gurupadapranayita, Mukhye satya vani vijayayi bhujayorviryamatulam, Hrdi svaccha vrtih sruramadhigatam ca sravanayor, Vinapyaisvaryena prakrtimahatam mandanamidam

Translation:

Beautiful hands are always the hands of the world to others, the great head is the one who always bows in front of the teacher, the beauty of the lips is the one who is always right, the shoulder is the one who has the power to win, the good heart is listening to the Vedas. For good people, those beauties are the best clothes, not wealth (Niti Sataka 53)

One of the mantra of Guru Strota reads: Ajnana timirandhasya jnana anjana shalakaya, chakshurunmilitam yena tasmai shri gurave namah (Servant born in the darkest ignorance, then the spiritual teacher opens the eyes of the servant with the lamp of science. The servant saluted with respect to him.

The spiritual teacher not only understands spiritual teachings in theory, but also he must have lived in these spiritual teachings. In Sanskrit there is the term Acarya which means he who teaches through his behavior. Acarya is not just an example, but he is also able to guide the people around him to follow the path of his life.

Thus, Tapini is the teacher in bebantenan who can guide sarati and Hindus who are holding ceremonies. Rightly Hindus in performing yajna ceremony to always mmeohon Ekuk instructions to either scale or abstract.

In Hindu teachings, the spiritual teacher has a noble place. He was even declared to be God. In Taittiriya Upanisad 7.11.2 mentioned maitrideva bhava, pitrideva bhava, acaryadeva bhava, atithideva bhava (mother is the embodiment of God, father is the manifestation of God, teacher is the manifestation of God, 
guest is manifestation of God. all kinds of truths of knowledge originating from God).

Position sulinggih in Hindu society is very noble so called sulinggih, meaning the main position. Besides being referred to as sulinggih it is also referred to as the Dwijati, meaning the second born. The first birth of the mother's womb as an ordinary human carrying karma wasana from a reincarnated atman. Karma wasana Karma consists of two groups, Swabhawa and Guna. Swabhawa are the seeds of nature, while Guna is the seeds of interest and talent.

The second birth is the birth given by a guru (nabe) who teaches Vedas according to regulations and gets them through Sawitri Mantram. This second birth went through a long process because Swabhawa and Guna directed at sacred and positive things from an early age, then various disciplines and sciences were taught in the aguronguron process lead by the nabe.

As Adi Guru Loka Pandita, it is not those who are only served as the pandita and dress the pandita through the diksa process. Those who are stated as pandita should those who already have the characteristics as stated in Kakawin Nitisastra 1.6, which is like the quote above. The people who are called to become pandita should go through a strict process of Hindu education and religious practice. Education and training can be done in the form of traditional education and training as well as in the form of modern education. After the existence of various advances can be manifested the nature and attitude of life as stated in Nitisastra 1.6, then the diksa ceremony and the pandita dress are worn.

Thus the four functions of the Pandita as stated in Sarasamuccaya 40 will be easier to do. The four functions of Pandita is the Satyawadi meant he was constantly talking on the truth of the Vedas. Apta means he who can be trusted by the people. Patirthan meant he was used as a place please ablutions by race and Panadahan Upadesa.
Pandita position as a highly respected by the people in general, because in this case there is change in the status of the walaka towards sadhaka. So that in the societal status a religious person has a status as a Pandita, who changed his name called amari aran, changed attributes (amari wesa) and changed life activities (amari wisaya) (Purwita, 1993:58).

Furthermore, Adi Guru Loka himself in his understanding was the sulinggih as the main leader and teacher in the community who had been able to appreciate the four main elements of Hinduism. Thus the importance of the position of a sulinggih in Hinduism, which until now is very much needed in the midst of the community, especially the Hindu community who can and are able to provide enlightenment both for human life itself even on the guidance of the ceremony so that he deserves to be the adi guru loka is the main teacher.

\subsection{Tapini Position as Tukang Banten}

The yajña will be determined by Tri Manggalaning yajña, namely the sarati, the yajamana, and the manggala. The yajamana is the performer of yajña, manggala is Sadhaka (Pandita), and sarati is the person who makes the means until it becomes an upakara and offerings.

To be a sarati, it takes readiness to carry out tasks because the work done is yajña. As a sarati, it always maintains self-purity by referring to the teachings of Tri Kaya Parisudha, is obliged to worship Dewi Tapini, namely the manifestation of Sang Hyang Widhi who guides his people who have a profession as sarati banten, accompanies and serves pemuput karya (Pandita/Pedanda, Pinandita when religious ceremony).

In preparing yajña ceremonial activities relating to religious ceremonies, for public and personal interests, sarati banten must first know the daily activities of people who will be made upakara yajña, type, and level of upakara which has become the agreement of Tri 
Manggalaning Yajña, just made an implementation schedule including the upakara structure yajña that will be implemented (Tim Penyusun, 2008:32).

Mapping the implementation of yajña, the first goal to be achieved is balance, then the form of upakara yajña as a whole is likened to a human body consisting of head, body and legs. After that, new types of banten were determined on the head, body and legs. The head in question is the main leader and the equivalent as a sanggar surya/sanggar tawang as a participant. Body is existing offerings in front of the main pelinggih/paselang, and legs are offerings that under such segehan and caru. All jejahitan are the skin. One simple mapping can be seen below.

a. Head: pejati, water for tirta.

b. Body: ayaban tumpeng pitu.

c. Legs: segehan putihkuning/segehan manca warna, tetabuhan.

The above description is for small yajña. In the process of making offerings there are several things that must be considered by sarati such as when making reringgitan/nues is a embodiment karma marga. The process must be truly lived out as a manifestation of the bhakti marga. The results of the mejejahitan are knowledge that is manifested clearly, namely jnana marga. At the time of nyorohan and make offerings must be based on purity of heart, with mona brata as a manifestation of the raja marga.

In larger ceremonies such as ngenteg linggih, the division of offerings is given by the instructions of Tapini, then sarati will divide Banten to sanggar sur $y a$, ayaban, and laapan or pengubengan. The truth is that sanggar surya is the tri angga part, namely the head, ayaban is the body part, and laapan or pengubengan is the part of the foot.

In making banten, it will be called sampian.

Anand Bhawanti Bhutani

Parjanyad Anna Sambhawah
Yajñad Bhawati Parjanto

Yaj Nah Karma Samudbhawah

Translation:

The existence of living things

because of food

Food due to rain

There is rain because of yajña

There is yajña because of karma

The sloka above implies that upakara and reringgitan complement the yajña series which is very important and needs to be preserved for generations. In Hinduism offerings and reringgitan is the language of religion unpacking applications in the sacred teachings of the Veda.

Traditional ceremonies are one of the elements of culture that standardizes the noble values of national culture that need to be explored, developed, encultured, capable of being transformed into future generations as virtuous humans. Ceremonies and upakara contain concrete elements and abstract elements.

The symbols are also used as a medium for Hindus to get closer to the Creator, hold a dialogue with Ida Hyang Widi Wasa to ask for protection and His Wara Nugraha. The above thinking is used to analyze Ssmpian or reringgitan which is full of symbols and also means standardizing various noble values of national culture. In Yajña Prakerti, offerings (upakara) has three meanings:

(1) Sahananing bebanten pinaka raja tuwi

(2) Pinaka warna rupaning Ida Battara

(3) Pinaka Anda Bhuwana.

The meaning of the symbol is a symbol of the omnipotence of God, the symbol of the universe and the symbol of ourselves. The illustration of banten peras is a struggle and prayer to achieve success in life. This is universally beneficial. The noble values contained in the sampian are also manifestations of Hinduism's devotion to their Lord.

In position as offering (banten) artisan, the Tapini will provide guidance in majejahitan, making sesamuhan (for the banten 
suci, pulagembal bebangkit, and catur), maki ng panjang ilang offerings for ngaben ceremony, and make offerings. In its capacity

artisan offerings, then Tapini have a duty to make banten catur and panjang ilang at the time of ngaben ceremony.

\subsection{Position Tapini as Leader Ceremony} In terms of sulinggih/pedanda istri who

will be pemuput the ceremony so that he would ngelokapasraya, then in addition to permission Guru Nabe, it must be approved also by sulinggih lanang to fulfill demand sisya and Hindus which sulinggih/pedanda lanang he was overwhelmed to receive the people's request. Therefore pedanda istri it was allowed to muput ceremony until pulagembal bebangkit. This is a progress in the struggle and justice gender for sulinggih/pedanda istri can be a leader yajña ceremony. As is often the case in Bali when a sulinggih/pedanda istri wants to be master of ceremonies, then had to wait formerly pedanda lanang death.

\section{Conclusion}

From what has been described, it can be concluded that the Tapini that a pedanda istri has a pretty good position as a goddess, as a teacher, as an artisan offerings, and as leader of Ceremonies. Perspective thealogy, then Tapini is the woman who can fight for gender equality and justice as it can be the master of ceremonies in addition to those inherent in him are as artisan offerings. There Tapini in Desa Pakraman Sanur as master of ceremonies who did not wait until pedanda lanang death so it is a progress for a Tapini to fight for feminists in the yajña ceremony.

\section{References}

Abdullah, Irwan. 1997. Sangkan Paran Gender. Yogyakarta : Pustaka Pelajar. Abdullah, Irwan. 2001. Seks, Gender, dan Reproduksi Kekuasaan. Yogyakarta: Terawang Press.
Adian, Dony Gahral. 2001. Tealogi Spiritualitas dan Keberpihakan pda Perempuan dalam Jurnal Perempuan untuk Pencerahan dan Kesetaraan Nomor 20 tahun 2001. Jakarta: Yayasan Jurnal Perempuan.

Artani, Ni Putu. 2013. Eksistensi Tapini dalam Upacara Ngenteg Linggih di Pura Dukuh di Desa Tegalalang Kabupaten Gianyar (Perspektif Pendidikan Agama Hindu). Tesis Program Pascasarjana IHDN Denpasar.

Etty, M. 2004. Perempuan Memutus Mata Rantai Asimetri. Jakarta: Gramedia.

Fakih, Mansour. 2007. Analisis Gender dan Transformasi Sosial. Yogyakarta: Pustaka Pelajar Offset.

Kiriana, I. N. (2017). Ngaben Conception In Lontar Siwa Tattwa Purana. Vidyottama Sanatana: International Journal of Hindu Science and Religious Studies, 1(2), 84-92.

Maswinara, I Wayan. 2007. Dewa Dewi Hindu. Surabaya: Paramita.

Parrinder, Geoffrey. 2005. Teologi Seksual Yogyakarta: LKIS.

Puspa, Ida Ayu Tary. 2013. Cili dalam Upacara Dewa Yajña di Desa Pejaten Kecamatan Kediri Kabupaten Tabanan (Kajian Teologi Perempuan). Denpasar: IHDN. Hasil Penelitian yang belum diterbitkan

Redig, I Wayan. 2008. Ikonografi Sakti dalam Siwaisme sebuah Fenomena Persoalan Gender dalam Pusaka Budaya dan Nilai-Nilai Religiusitas. I Ketut Setiawan (Ed). Denpasar: Fakultas Sastra Unud.

Sokaningsih, I Made. 2007. Upacara Pemujaan Durga Mahisasuramardini. Surabaya:Paramita.

Subali, Ida Bagus. 2008. Wanita Mulia Istana Dewa. Surabaya: Paramita.

Surayin, Ida Ayu Putu. 2005. Melangkah Ke Arah Persiapan Upakara-upakara Yajña.Surabaya : Paramita.

Tim Penyusus. 1985. Himpunan Keputusan Seminar Kesatuan Tafsir terhadap 
Aspek-aspek Agama Hindu I-XV. Widia, Wayan, dkk. 1990. Cili sebagai Denpasar: PHDI Pusat.

Lambang Dewi Kesuburan di Bali. Denpasar: Departemen Pendidikan dan Kebudayaan Direktorat Jenderal Kebudayaan.

Simbol dalam Agama Hindu. Surabaya: Paramita.

Titib, I Made. 2004. Purana Sumber Ajaran Hindu Komprehensif. Surabaya: Paramita.

Wijayananda, Ida Mpu Jaya. 2003. Tetandingan lan Sorohan Bebanten. Surabaya: Paramita.

Wiana, I Ketut.2009. Suksmaning Banten. Wijayananda, Ida Pandita Mpu Jaya. 2004. Surabaya: Paramita.

Makna Filosofis Upacara dan Upakara. Surabaya : Paramita. 